\section{SAAAA \\ JOURNAL}

Journal of Archaeology and Fine Arts in Southeast Asia

\title{
Pamanang Kulinarya: Developing a Safeguarding Plan for Culinary Heritage Using the Statement of Significance - The Case of Lomi in Lipa City, Batangas, Philippines
}

Jame Monren Tapalla Mercado

Graduate Student, Instructor and Research

Associate

The Graduate School, College of Tourism and Hospitality Management \& Research

Center for Social Sciences and Education

University of Santo Tomas

Manila, Philippines

jtmercado@ust.edu.ph

Eric Babar Zerrudo

Director

The Graduate School - Center for

Conservation of Cultural Properties and the Environment in the Tropics (CCCPET),

University of Santo Tomas

Manila, Philippines

ust_cccpet@yahoo.com

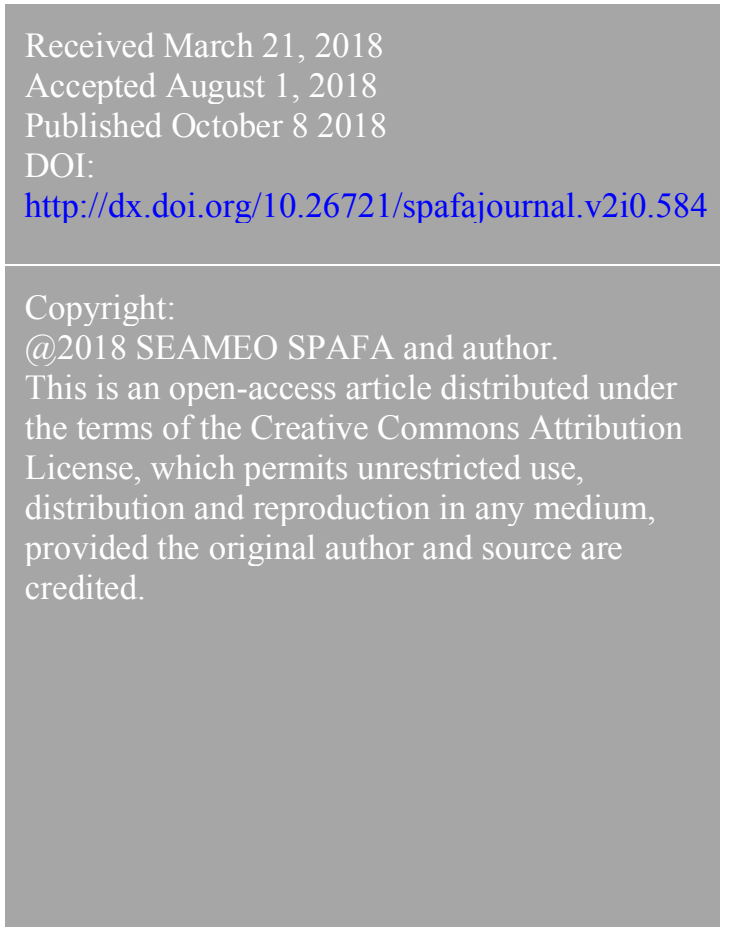

\begin{abstract}
Heritage constitutes the identity of a community. An important heritage of a community is food, often defined as culinary or gastronomic heritage. This mixedmethod research developed a safeguarding plan for culinary heritage, specifically for lomi in Lipa City, Batangas, using the Statement of Significance. Different theoretical paradigms were used, especially anthropological theories like acculturation and modernization, and conservation frameworks such as UNESCO, ICOMOS and GCI heritage charters and conventions. To trace the significance of lomi, the researchers collected physical evidence by visiting and observing lomi houses, or lomians
\end{abstract}


(restaurants dedicated to serving the lomi dish), in Barangay Poblacion focusing on the preparation of this food using Cultural Heritage Mapping and SWOT Analysis; oral evidences by conducting focus group discussions; in-depth interviews with different stakeholders; surveys in the local community; and archival evidence from different journals and books. Lipa lomi is significant in its historical, culinary, aesthetic, economic, health, social and symbolic aspects. Historically, it was introduced by To Kim Eng, a native from Amoy (now Xiamen) who established the first lomian in the city, Panciteria de Lipa. As the community accepted this culinary tradition, different lomians were established not only in the city but also in the whole province and became a localized business industry. Even though it was Chinese in origin, it follows the characteristics of Batangas cuisine wherein it focuses on the natural flavour of fresh ingredients and the simplicity of the cooking methods. Also, it is economically important because it became a good source of income and because of its affordability as a commercialized dish. Socioculturally, the culinary tradition is also important for the local community and its relationship to their religious culture. Perspectives of different stakeholders on the characteristics and identities of Lipa Lomi are identical and acceptable but it changes based on trends, issues and constraints. For the stakeholders, viability is important for the culinary tradition as it is agreed that it is one of the culinary identities and an attraction of Lipa and its community. Stakeholders also have their own movement to safeguard and sustainably develop the culinary tradition. A proposed culinary safeguarding plan was established based on the results of the research.

Keywords: culinary heritage, Lipa City, lomi, safeguarding plan, Statement of Significance

\section{Introduction}

The province of Batangas, Lipa City, is rich in history and heritage. Historically, it was considered as the world's top producer of coffee during the Spanish era and was given the title "La villa de Lipa" (or the City of Lipa) (Topografico de Ricardo Fe, 1887). Lipa is also known for its culinary treasures. Some of these are kapeng barako (native coffee), bulanglang (vegetable soup), sinaing na tulingan (simmered salted fish), Pan de Agua (a native bread) and lomi, a dish with Chinese influence.

Lomi, a Chinese-inspired noodle, is one of the trademarks of Lipa City used for generating profits by the local community (Polistico 2016). A lot of lomians were developed, especially near the major roads and highways of the city, such as Lomi King and Panciteria de Lipa. It was a Chinese-influenced food brought to the city by To Kim Eng, a Chinese businessman who migrated to Lipa and was known to be the person who introduced lomi to the community (Tayag and Quioc 2012), to the Lipeños then it was developed through time especially on appearance, taste and texture. As it became commercialized, some aspects of its significance started to deteriorate especially on the ingredients, process of cooking and its consumption because of modernization, current trends, immediate demands of the customers and the perspective of the "fast food" ideology.

This research addresses the problem of how to come up with a safeguarding plan for culinary heritage using the statement of significance specifically in the case of the 
lomi of Lipa City, Batangas, Philippines. The research also aims to achieve the following objectives: (1) to understand the different significant aspects of lomians as an aspect of sociocultural identity of the city of Lipa based on historical, culinary, aesthetic, economic, social and symbolic aspects; (2) to discuss issues related to the transmission of cooking lomi as an intangible heritage; (3) to determine how Lipeños transmitted the culinary tradition from one generation to another; (4) to identify the efforts of the different stakeholders (local government of Lipa, non-governmental heritage, cultural and tourism organizations, owners of lomians, tourists and the Lipeños) in conserving this culinary tradition and developing it in a sustainable manner; (5) to determine the practices of the local community especially on the preparation, the significance of lomi in the community, the raw ingredients and materials (tangible), the process of cooking, preparation, presentation and how it is transmitted from generation to generation and how lomi is served to the customers based on its culinary heritage integrity and significance; and (6) to create a standard safeguarding plan framework designed for the lomi industry of Lipa City.

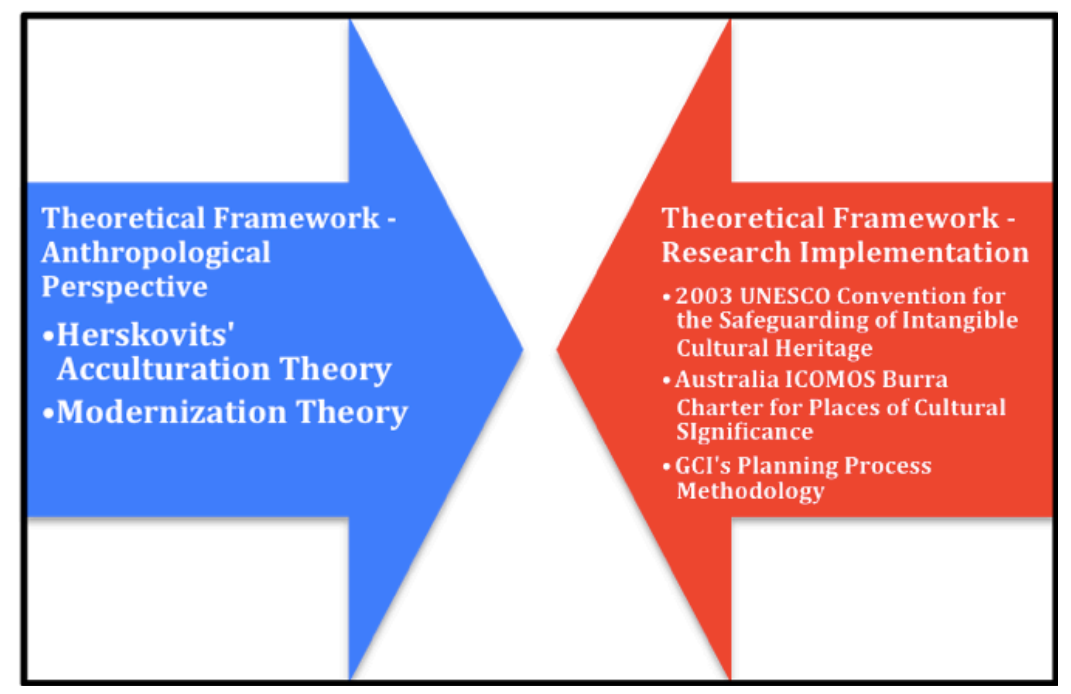

Fig 1. Representation of the research's theoretical framework

Figure 1 represents the theoretical frameworks used in the study, which are divided into two perspectives: the anthropological perspective and the research implementation perspective. In the anthropological perspective, the researcher identified two theoretical approaches that characterize the culinary tradition of lomi in Lipa: lomi as a culinary tradition introduced by the Chinese and now embraced by the community as their own culture (Acculturation Theory); and today's lomi has evolved due to the influence of current trends and issues like the influence of food preservatives and additives; modern technology, equipments and materials for cooking; new process of cooking and the developing needs and wants of the people (Modernization Theory). In the research implementation perspective, the frameworks will be used as a basis for the collection and analysis of research findings and data and to provide recommendations for the safeguarding of the lomi culinary tradition. The 2003 UNESCO Convention offers the basis for implementing intangible heritage documentation, determining the influence of different stakeholders for conservation and development, and providing provisions on promoting the culinary tradition and developing a safeguarding plan for the sustainability of the lomi tradition. For the 
1999 Australia ICOMOS Charter, the researchers used the details regarding heritage significance identification by means of determining the physical, oral and documentary evidences, and providing a comprehensive statement of significance (SOS). Lastly, for the GCI Planning Process Methodology, the researchers consider the provision of the influence and importance of the economic aspect on heritage resources.

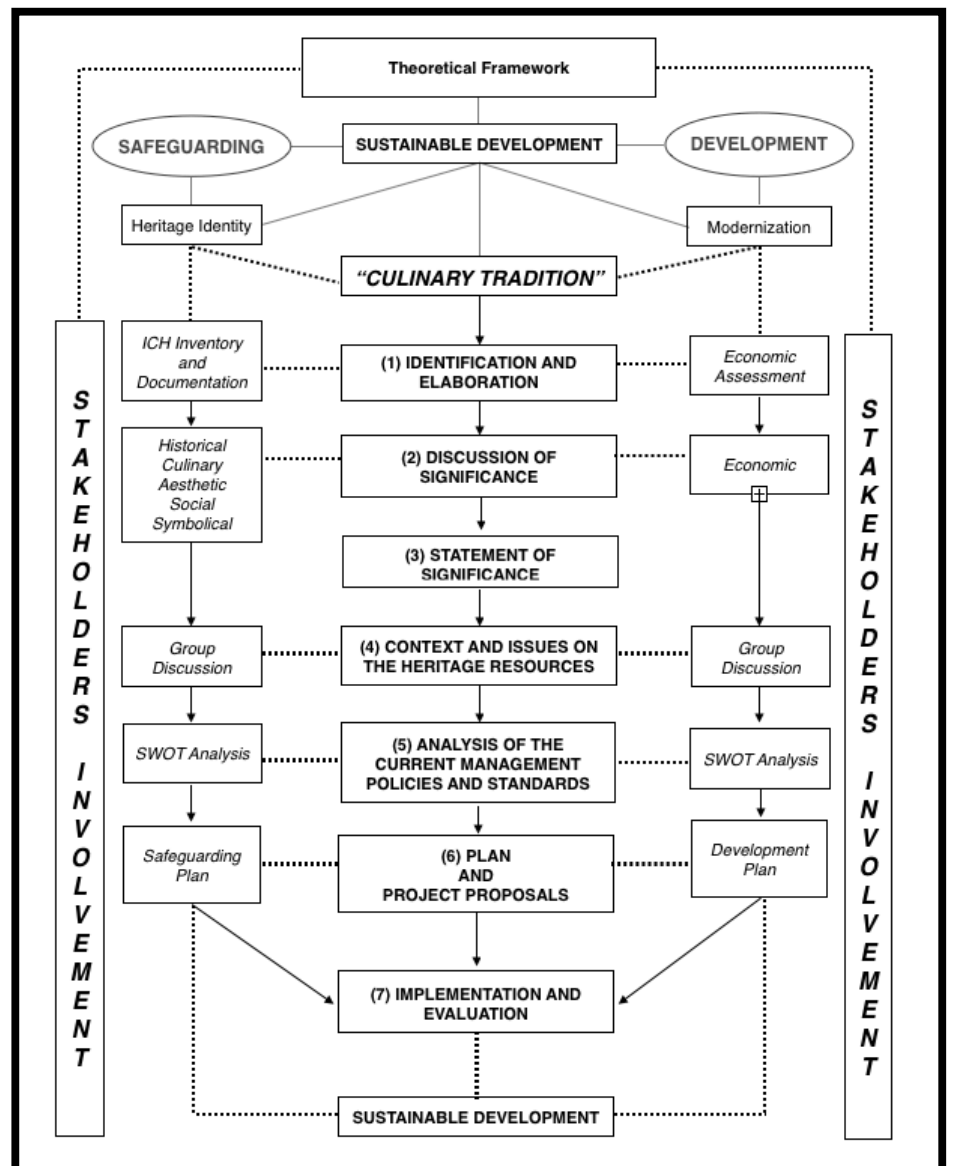

Fig 2. The culinary heritage significance and sustainable development conceptual framework

As shown in Figure 2, the framework is divided into seven different parts; each has a distinctive procedure for safeguarding and developing the culinary tradition of lomi sustainably. The first step is identification and elaboration, which determines the culinary tradition of lomi by means of the intangible cultural heritage (ICH) inventory and documentation or cultural heritage mapping and the tourism activity assessment. ICH inventory and documentation will determine the culinary tradition and its details. The economic assessment will identify the current business situation of the locality with a particular focus on the status and development of business profitability and customer acceptability. This assessment must be based on the different lomians especially in the subject site (Barangay Poblacion 1 to 11, including 9-A). The second step is to discuss the significance based on different aspects, generally on the sociocultural and economic. From the details regarding the significances, a summarized statement must be formulated. This statement will be the basis for any safeguarding and development plans and projects for the culinary tradition. Then the different contexts and issues of the culinary tradition are determined by means of 
physical observation and oral evidences using in-depth interviews from different stakeholders and a focus group discussion. An analysis of the current management policies and standards or the current governance from a certain group must be done through SWOT analysis (Strengths, Weaknesses, Opportunities and Threats). The procedure will examine the internal and external environment that can affect the management and development of the culinary heritage. The assessment is being done to understand the positive and the negative details of the management so that any changes and possible recommendations will be implemented. After determining the resources and the current practices from the management body, different plans and projects will be formulated, which will identify safeguarding (Safeguarding Plan) and development. These projects must be sustainable especially if they affect the sociocultural, economic and even environmental aspects of the community.

\section{Literature Review}

\section{Pamana (Heritage): Heritage of the Community}

People normally recognize culture and heritage as the same with regard to its definition and significance to the community. However, based on the theoretical and conceptual researches and studies from the academic field, these two are different concepts but related to each other. However, the most valuable and universally approved definition of heritage comes from the United Nations Educational, Scientific and Cultural Organization (UNESCO). Based on the 2001 UNESCO Universal Declaration on Cultural Diversity, "culture is a way of living that includes behavior patterns, arts, beliefs, institutions and all other products of human work and thought shared that reflect the identity of a group" (UNESCO, 2002). Then according to the UNESCO World Heritage Centre, "heritage is a legacy from the past, what people live with today, and what an individually or group of people collectively pass on to future generations" (UNESCO, ICCROM, ICOMOS \& IUCN, 2013). In the definition of heritage, legacy would pertain to what a particular person or community inherits from other persons or from other communities, or adapted from one race to another. The important point is that it must be continuously transferred from one generation to another generation (Bessiere 2013). And as a person or the community continuously practises it, it becomes their identity or represents and characterizes them (Bessiere 2013).

\section{Cultural Expressions: Intangible Cultural Heritage (ICH) in the International and National Setting}

Intangible cultural heritage is considered as an identity and the story of the community (UNESCO World Heritage Centre 2003). This translates to what and how the community expresses their tradition, customs and beliefs, which then become an ordinary practice or lifestyle. An individual or a community transmits these heritages from one generation to another orally or by gesture. The transmission of intangible heritage is an indication of giving respect and honour to the cultural significances and human creativity of the community (UNESCO 2003). At some point, when intangible heritages are transmitted, an individual or the community changes some of the details. The heritage is modified based on how people understand its significance, the complexity of the heritage practice, availability of the needed materials and other 
related things, the human creativity and skills development, the documentation of the heritage and the influence of modern information and technology.

The 2003 Convention for the Safeguarding of the Intangible Cultural Heritage is to ensure international recognition from the different member states and to guarantee a ratification of their own national legislation regarding the contents of the convention. The 2003 Convention aims at safeguarding intangible cultural heritage that is in step with international agreements on human rights and that meets requirements of mutual respect among communities and of sustainable development (UNESCO 2003).

Moreover on the part of the member states, especially those who ratified the convention, they are asked to identify the different ICH in their own national territory, conduct proper documentation and inventory; and implement conservation efforts to sustain the community's identity and value. The convention also recognizes outstanding ICH that delivers a universal value (Representative List of Intangible Cultural Heritage of Humanity) and ICH that has an urgent need for conservation (List of Intangible Cultural Heritage in Need of Urgent Safeguarding). The convention also determines the proper documentation of the ICH and creates a concrete action plan on ICH conservation and sustainable development coming from the government and the community.

The 2003 UNESCO Convention identifies five domains of the ICH. Domains are considered as the classifications of ICH based on what an ICH highlights and its identity to the community. Each ICH can be classified as one or more than one domains. The domains of the ICH are as follows: oral traditions and expressions; performing arts; social practices, rituals and festive events; knowledge and practices concerning nature and the universe; and traditional craftsmanship (UNESCO 2003:4).

As part of the Convention, state parties are required to safeguard their own ICH by identifying and documenting it. "Identification is a process of describing one or more specific elements of intangible cultural heritage in their own context and distinguishing them from others" (UNESCO 2003:4). Then after determining the different ICH within the national territory, this will lead to documenting or making a master list. This is being done to monitor the available ICH and to set priorities for ICH that needs an immediate conservation procedure. This will also determine research and study about the nation's ICH and its significance.

On the part of the Philippines, a law was ratified and amended under the Philippine Constitution that represents as the government's reply from the amended 2003 UNESCO Convention, the Republic Act No. 10066 or also known as the National Cultural Heritage Act of 2009. This law focuses on the "conservation and promotion of the nation's cultural heritage; to completely establish the National Commission for Culture and the Arts; and to protect the welfare of the cultural workers in the country" (Congress of the Philippines 2009). Under the law, the government protects the significance and value of ICH by creating the National Inventory of Intangible Cultural Heritage - specifically the Philippine Intangible Cultural Heritage Committee in collaboration with the UNESCO National Commission of the Philippines (UNACOM) (Art. 5 Sec. 19). The government is responsible for documenting the $\mathrm{ICH}$ of the Philippines and to secure that it is continuously practised and interpreted properly by the community. This also assures proper information dissemination of 
ICH to the community by all means such as integration in the curricula from the basic education to the postgraduate studies and tourism.

\section{Pangkabuoan at Kahalagahan (Integrity and Significance): Heritage Integrity and the Statement of Significance}

Integrity, in heritage context, is "a measure of the wholeness and intactness of a heritage resource and its attributes to secure, sustain and convey its significance" (Andrus and Shrimpton 2002 cited in Stovel 2007: 23). It identifies every detail of a heritage resource that contributes to its significance and value. These details will tell the story of a certain heritage and how it is important in the community. In built heritage, the integrity includes the materials, forms, process of its construction and usage. For intangible heritage, the integrity will depend on the reason why it was performed or practised, the tangible used, the process of doing, the presentation, its significance to the community and how it is being transmitted from one generation to another (Horng and Tsai: 2012).

Heritage integrity is co-related with heritage value or significance. Significance, according to LeBlanc (1993: 3) pertains to "the importance, relevance and meaning of a heritage resource to an individual or a group of people". This will make a heritage resource distinct from other heritage resources. It discusses why it is important in certain aspect and why the community must conserve it for future use. There are numerous frameworks that determine the significance of a heritage resource based on international conventions and charters. Some of the well-known frameworks are the Australia ICOMOS Burra Charter of Places of Cultural Significance (Australia ICOMOS 2013) and Assessing the Value of the Cultural Heritage (The J Paul Getty Trust 2002).

\section{Kulinarya (Culinary): Heritage from the Sense of Taste and Place}

Culinary tradition is an essential identity of the community (Reynolds 1993; Westering 1999; Di Mauro et al. 2011; Lucin 2013; Council on International Education Exchange n.d.). It is because all aspects that describe food are connected to the historical, anthropological and cultural dimensions of the community (Visser 1991). These aspects are related to the reason why the community prepares the food, the significance of food, the raw ingredients and materials used (tangible), the process of cooking, preparation and presentation, and how it is transmitted from generation to generation (Kivela and Crotts 2006). It all started from why it is being prepared and why food is important socioculturally. Like the common belief of the Filipinos that cooking and preparing noodles during birthdays will give a person long life or preparing sticky kakanins (traditional rice cakes) will bind family ties and friendship.

Hence, food is used in important events that happen to a person or to the community (Alejandro et al 2008; Lee 2015). For instance, if a person cooks pansit (Filipino noodles) or the Filipino style spaghetti (cooked in tomato sauce), some would think they are celebrating a birthday of a person. Litson (roasted pig) is prepared for very special occasions such as piesta (fiesta).

It is also important to know how raw materials are produced and gathered (Alejandro 1998). Agriculture, fishing and husbandry are common industries of the community that produces raw materials such as rice, grains, vegetables, fruits, animal meats and 
the like. These are part of the community's everyday lifestyle and considered to be their culture.

It is also important to study the materials being used for cooking. When Filipinos cook sinigang (sour-based soup), traditionally, people tend to use a palayok (clay pot), which is handmade and has undergone a traditional process. Another example is the kudkuran (traditional Filipino coconut meat shredder), which is used to shred the meat of a mature coconut to produce coconut cream and the milk. One of the dishes of the Philippines that uses coconut cream and milk is laing, a Bicol dish made of the stalks and leaves of gabi (taro plant) (Fernandez 1988).

The use of traditional and local ingredients and materials is a vital component in the integrity and identity of the dish (Mora 1998; Horng and Tsai 2012). These ingredients show the integrity of the food and contribute to the conservation and preservation of the culinary tradition.

Culinary traditions are also significant based on its landscape and setting. Food is associated on the place's geographical entity, agricultural aspect, indigenization and cultural influences; unique traditions and practices of the local community; historical contribution and development; sociological influences like acculturation and demonstration effect and the like (Alejandro, 1998; Fernandez 2000; Barham 2003; Trubek 2008; Trubek and Bowen 2008; Alvina and Roces 2016). With this, the associated traditions and customary practices in culinary heritage are always linked and significant to the local community. It also shows that food serves as an identity of the place and is critical to its image, either for its cultural and heritage aspects or for economic provisions like business and tourism (Barham 2003; Trubek 2008; Trubek and Bowen 2008; Roland 2013). That is why for most places either in the international or in the Philippine setting, localizing, regionalizing or nationalizing a dish is significant (Alejandro 1998; Roland 2013)

\section{Pangangalaga (Safeguarding): Context and Issues of Safeguarding for Culinary Heritage in the International and National Setting}

In culinary heritage, there are programmes and projects from different international and Philippine institutions to sustainably conserve the significance of culinary heritage. In the international setting, UNESCO included gastronomy as part of the representative list of intangible cultural heritage of the humanity (UNESCO 2003). Just like the UNESCO World Heritage Site recognition, the intangible heritage of humanity recognition also has its own criteria for selection (UNESCO 2003: 6).

With this recognition, intangible heritage will be prioritized for conservation by means of providing technical assistance from different professionals, international cooperation for the protection of the heritage resource and will be entitled to apply for the intangible cultural heritage fund (UNESCO 2003). Some of the culinary traditions that were listed under the intangible cultural heritage of humanity and considered as tourism resources are lavash, traditional Armenian bread from Armenia (UNESCO 2014 and Armenia); the Mediterranean diet, a transnational ICH from Cyprus, Croatia, Spain, Greece, Italy, Morocco and Portugal (UNESCO, Cyprus, Croatia, Spain, Greece, Italy, Morocco and Portugal 2013); traditional Mexican cuisine from Mexico (UNESCO and Mexico 2010); Turkish coffee culture and tradition from 
Turkey (UNESCO and Turkey 2013); and washoku, traditional dietary cultures of the Japanese, notably for the celebration of New Year (UNESCO and Japan 2013).

As culinary tradition can also be used for tourism development of an area. The United Nations World Tourism Organization (UNWTO) sets its initiative to create the UNWTO Gastronomy Network for the conservation and promotion of local culinary traditions and offerings that are being used for tourism activity. This organization is a forum in which different professionals and experts in the field of gastronomy and gastronomic tourism from affiliate members and member states can work together "to promote and shape the future of gastronomy tourism, providing the ideal forum for public-private partnership" (UNWTO 2017). The UNWTO Global Code of Ethics for Tourism (GCET) and the 2030 Agenda for Sustainable Development are the frameworks used by the organization on how to sustainably use the local culture of food for tourism purposes and create conservation and preservation policies and programmes (UNWTO 2001).

With the integration of the ASEAN Community in 2015, the ASEAN Tourism Standards were created to standardize the requirements and qualifications of different tourism establishments in the ASEAN region. It is divided into six standards and one of them pertains to Food and Beverage Services (ASEAN n.d.). Standards on the operation, management and even conservation of local culinary offerings are identified in the standards under Food and Beverage Services. Local Food and Beverage Services "is a form of service where traditional and typical food and beverage are produced and/or sold by local people at food stalls, local restaurants or other similar outlets" (ASEAN n.d.). Under the standards, it examines nine major criteria of the local food establishment: (i) design and construction of food premises, (ii) facilities, (iii) food and utensils storage, (iv) food processing, (v) food disposal, (vi) health and hygiene of food handlers, (vii) cleanliness, (viii) maintenance, and (ix) quality level (ASEAN n.d.).

In the Philippine setting, as culinary tradition is being considered as a tourism and travel resource, the Department of Tourism (DOT) included it in the National Tourism Development Plan (NTDP) 2011-2016 during the presidency of Benigno Simeon Aquino III. The NTDP 2011-2016 is a comprehensive tourism development plan of the Philippines provided different strategies on how to provide programmes and projects on the development and even conservation of different tourism programmes. One of the strategies of the NTDP was providing programmes for developing and marketing competitive products and destinations (Philippine Department of Tourism 2012).

Culinary resources are considered as one of the top tourism products of the Philippines (Buenavente 2009). It is because of its uniqueness and definitely the taste that most of the foreign tourists really love (Tayag \& Quioc, 2012). Moreover, to make the Philippines as the next culinary destination, during the stewardship of Secretary Joseph Ace Durano of the Department of Tourism, the Department launched Kulinarya Filipina, a project that provided culinary tour packages for both foreign and local tourists. This also strengthened the conservation and preservation efforts for localized culinary traditions to sustainably use it for tourism and travel purposes. Travel agencies and tour operators offered the packages particularly to 
members of the Philippine Tour Operators Association (PHILTOA) and the Philippine Travel Agencies Association (PTAA) (Buenavente 2009). Highlighted destinations for the Kulinarya Food Trips were based on the present top destinations, considering both domestic and international tourist inflows, or a destination which is well known because of its food and related attractions.

There is also an effort to declare the month of April as "Buwan ng Kalutong Pilipino" (Month of Filipino Culinary). It was petitioned by Chef Jam Melchor from the Philippine Culinary Heritage Movement (PCHM) to the National Commission for Culture and the Arts (NCCA) (Melchor 2016). The Office of the President (OP) has already approved the petition.

There are also food-writing competitions in the Philippines that promote the significance of culinary heritage and how to conserve it for sustainable use using comprehensive research. The Doreen Gamboa Fernandez Food Writing Award is an annual food-writing competition open for all writers and researchers who want to share a specific culinary tradition by means of writing a literary essay (Sta. Maria 2005). From this competition, different publications have been published in order for the public to have access to the award-winning articles.

Individual researchers also conducted their own researches on how to properly conserve and protect the intangible cultural heritage of culinary traditions of the Philippines. One of those researches was proposed by Felice Prudente Santa Maria, a prominent Philippine culinary heritage researcher. Her study, GAMBILA: A Preliminary Framework for the Study of Philippine Culinary History with Multidisciplinary Impact on Contemporary Social Reality (Sta. Maria 2005), highlighted the importance of culinary heritage research, the different efforts to highlight Philippine culinary heritage by means of publications, events and programmes, and proposed a research framework for studying culinary heritage of the Philippines (Sta. Maria 2005).

\section{Lomi: The Hot Noodle Soup of Lipa}

In Southeast Asian countries, there are countries that showcases different culinary heritages especially concentrating on noodle soup either thin-based or thick-based broth (ASEAN, 2014). For Vietnamese, they are known for their Pho, which is a noodle soup made from beef or chicken broth and rice noodles. This is also unique on its complimentary variants of herbs and spices like fresh mint, cilantro, basil, bean sprouts, limes and sliced chilli peppers that can be paired with Pho (Greeley, 2002). For Thai people, they have Thai Noodle Soup, which highlights the use of coconut milk as part of the stock (ASEAN, 2014). Different meats can be added that serves as the main flavour of the soup.

In Malaysia and Singapore, there is a thick noodle soup called as Lor mee or also known as the gravy noodles. It is consists of "braised eggs, ngoh hiang (five spice meat rolls), fish cakes, braised pork and fried fish fritters and a flourish of Chinese parsley, chopped spring onions and yellow noodles" (Michelin Guide, 2018). It was introduced by the Chinese especially coming from the Fujian province or the southern part of China (Lim, 2012). In the Philippines, there is a noodle soup that is the same 
with the characteristics of Lor mee, which is also influenced by Fujian cuisine. It is called Lomi specifically in Lipa City, Batangas.

Lomi is considered as a foreign-influenced dish, specifically coming from Fujian cuisine that is completely embraced by the Batangueños especially in Lipa City because of its historical significance. In Fujian cuisine, lomi is a breakfast dish that most of the heads of the families' request (Palanca et al. 2015). It is a thick egg noodle soup that is a mixture of egg noodles, vegetable and different kinds of meat toppings such as kikiam (Chinese fried meatloaf), pork, chicken, beef, liver, shrimp and squid. The soup base is a meat stock that is a combination of pork belly and/or a whole chicken (Palanca et al. 2015). However, in Batangas, lomi does not contain any vegetables. It consists only of meat, noodles and the thick stock or the gravy, which is thickened with a slurry, a combination of water and cassava starch. Another unique characteristic of lomi in Batangas is that it is served with a dipping sauce (sawsawan), which is a mixture of soy sauce, calamansi juice and chopped red onions and sometimes with bird's eye chilli (siling labuyo) based on the preference of the person eating it. This sawsawan is not mixed automatically into the lomi but it must be mixed in a separate saucer. As a person eats the lomi, they put a little of the sawsawan in one part of the soup then mix it and get the part where there is the sawsawan.

Lomi also has its food accompaniment just like puto-dinuguan (rice cake and pork blood stew) and tuyo and champorado (dried fish with chocolate rice porridge). For lomi, the best partner for it is bread specifically in the Municipality of Cuenca; they call it Pan de Agua (bread of water) (Uy and Orillos 2015).

Lomians are present in most of the municipalities and cities of Batangas, especially in San Jose, Ibaan, Rosario, Batangas City, Cuenca and in Lipa City, known to be the home of the first lomi. There are no differences from one municipality/city to another in the preparation and taste of lomi in the province of Batangas, but Lipa City's lomi is important because of its historical identity in introducing lomi to the dining tables of the Batangueños. Panciteria de Lipa, established in 1968, is considered as the first lomian in Lipa and in Batangas that introduced lomi to the community. A pure Chinese and the owner, To Kim Eng, at first cooked lomi for his mahjong friends as merienda (snack) (Tayag and Quioc 2012). Then, when Kim Eng and his wife noticed that there were a lot of people requesting lomi, they decided to put up a restaurant and put up some tables and chairs outside their house. As the number of customers increased, they decided to put up a restaurant located on Kapitan Simeon Luz Street near the public market (Tayag and Quioc 2012).

But how did the culture of lomi spread all over Batangas? The answer: To Kim Eng, the owner of Pansiteria de Lipa, shares every single detail of the process of cooking it to interested people. His philosophy for this is that he wants to help other people. As he always says, "It is good to share the know-how of cooking lomi so that others may have a source of income as well" (Tayag and Quioc 2012). To continue the tradition of his family, the process was also shared with their siblings and grandchildren. 


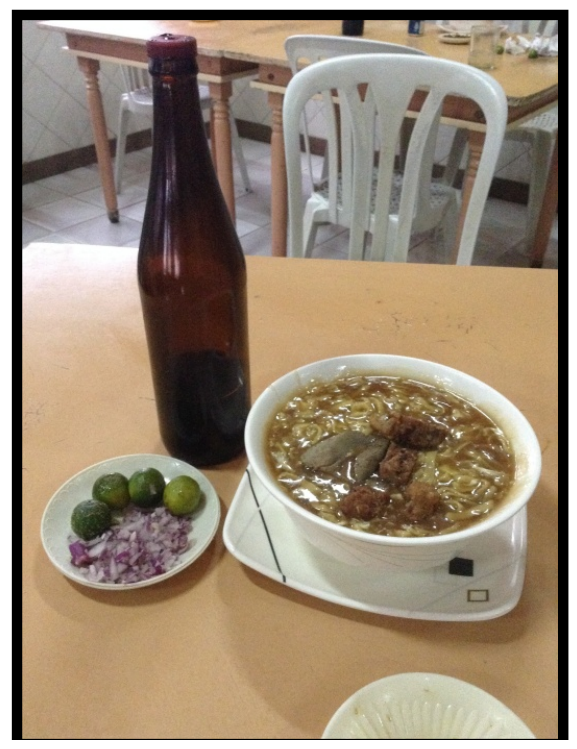

Fig 3. The original lomi from To Kim Eng's Pansiteria de Lipa together with its traditional sawsawan (Source: Mercado, 2016)

\section{Research Method}

The research is a mixed-method type (quantitative and qualitative) or methodological triangulation (Easterby-Smith et al. 1991) where the results are based on three major evidences for determining heritage significance: physical, oral and documentary/archival (Australia ICOMOS 2013). The researchers used the following tools in relation to the research's theoretical frameworks:

\begin{tabular}{|l|l|l|}
\hline $\begin{array}{c}\text { Major Evidences in } \\
\text { Heritage Significance } \\
\text { Research }\end{array}$ & \multicolumn{1}{|c|}{$\begin{array}{c}\text { Theoretical } \\
\text { Framework }\end{array}$} \\
\hline & $\begin{array}{l}\text { Research Tool } \\
\text { Physical (examination of } \\
\text { the heritage resource) }\end{array}$ & $\begin{array}{l}\text { Provision to utilize the } \\
\text { Theoretical Framework } \\
\text { Research } \\
\text { and SWOT analysis } \\
\text { Implementation (2003 } \\
\text { UNESCO Convention } \\
\text { on the Safeguarding of } \\
\text { Intangible Cultural } \\
\text { Heritage, Australia } \\
\text { ICOMOS Burra } \\
\text { Charter for Places of } \\
\text { Cultural Significance } \\
\text { and the GCI Planning } \\
\text { Process Methodology } \\
\text { (The J Paul Getty Trust } \\
\text { 2002)) especially in the } \\
\text { proper documentation } \\
\text { of Lipa City Lomi } \\
\text { Culinary Tradition }\end{array}$ \\
\hline
\end{tabular}




\begin{tabular}{|c|c|c|}
\hline $\begin{array}{l}\text { Oral (determining factual } \\
\text { and insight information } \\
\text { from the people } \\
\text { stakeholders) }\end{array}$ & 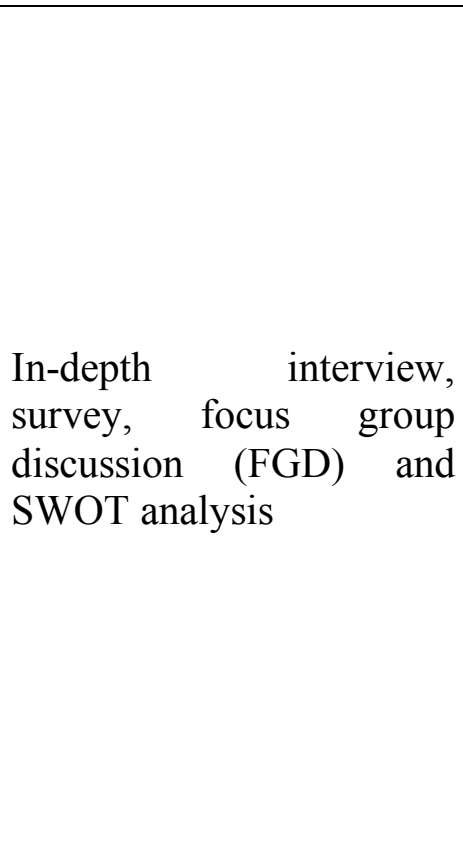 & $\begin{array}{l}\text { Provision to utilize the } \\
\text { Theoretical Framework } \\
- \text { Anthropological } \\
\text { Perspective } \\
\text { (Herskovits, } \\
\text { Acculturation Theory } \\
\text { and the Modernization } \\
\text { Theory) especially in } \\
\text { determining the } \\
\text { acceptability of the } \\
\text { stakeholders on the } \\
\text { culinary tradition and } \\
\text { the emerging and } \\
\text { current issues, } \\
\text { opportunities and } \\
\text { constraints, especially } \\
\text { on the development and } \\
\text { safeguarding }\end{array}$ \\
\hline Documentary/Archival & $\begin{array}{l}\text { Published journal articles, } \\
\text { books and other reading } \\
\text { references related to } \\
\text { culinary heritage and } \\
\text { community identity }\end{array}$ & $\begin{array}{l}\text { Provision to utilize both } \\
\text { Theoretical } \\
\text { Frameworks - } \\
\text { Anthropological } \\
\text { Perspective and } \\
\text { Research } \\
\text { Implementation) that } \\
\text { served as guide in the } \\
\text { execution of the } \\
\text { research }\end{array}$ \\
\hline
\end{tabular}

Table 1. Selected research tools and their relationship to the theoretical frameworks of the research

To understand fully the research tools that were used by the researchers, the following descriptions are presented:

- Cultural heritage mapping (CHM) is the process of identifying natural and cultural heritage resources of a specific locality for the purpose of conservation and development (Commonwealth Department of Communication and the Arts 1995; Zerrudo 2008). For this study, the researchers used the Intangible Cultural Heritage Template to determine a comprehensive detail of lomi for every lomian.

- In-depth interviewing is a qualitative research tool that seeks to determine comprehensive insight from a person with the condition of having only a small group of respondents (Boyce and Neale 2006).

- Survey - After conducting the survey, the researchers analysed the answered questionnaires then transmitted the results of the survey using statistical graphics and figures. This will ensure readable and easily comprehensible results of the study. 
- Focus group discussion (FGD) is composed of six to ten people and facilitated by a moderator who is related to or specialize in the topic being discussed (Eliot and Associate 2005).

- SWOT analysis (strengths, weaknesses, opportunities and threats analysis) "guides you to identify your organization's strengths and weaknesses $(\mathrm{S}-\mathrm{W})$, as well as broader opportunities and threats (O-T)" (University of Kansas 2016).

- Reading and analysing published journal articles and books

For the survey method, the researchers made a questionnaire that focuses on the perspective of the local community with regard to lomi and its heritage significance to the area. The researcher also determined the total number of people living in the subject site (Urban Barangay - Barangay Poblacion 1-11, including 9-A) based on the record of the Philippine Statistics Authority. The total population of the Urban Barangay - Poblacion (Barangay 1-11, including 9-A) of Lipa City is 22,731 sourced from the 2010 Philippine Standard Geographic Code (Philippine Statistics Authority 2016). Using the Slovin's formula, 396 respondents are needed to answer the selfmade questionnaire. The margin of error (e) used is $5 \%$ or 0.05 . Thirty-three respondents are needed for every barangay (local community district).

For the ethical consideration of the research fieldwork, the researcher conceptualized and distributed letters of intent to the participants. The letters highlighted the significance of the study and the provision of using the gathered information for academic purposes. Copies of the questionnaire were also attached to the letters. During the conduct of the research fieldwork, the researcher did not control certain answers provided by the participants and all information were strictly confidential.

For the survey, the researcher also distributed letters of intent to the local government and to the different barangays regarding the research. Before conducting it, approval from the respondents were received. A cover letter and a consent form were also attached to the questionnaire to properly explain the significance of the study and to practice research ethical consideration.

\section{Results and Discussions}

Kwento ng Lasa (Story of the Taste): Statement of Culinary Heritage Significance Lomi is a symbol of Chinese influence in the city of Lipa, a dish that has its roots in Fujian cuisine, then fully integrated into the local community who have added their own local flair to the dish to the point that it now has its own trademark or identity. That's why a lot of locals and even people from other places patronize the dish.

The culinary tradition, as it is part of the common lifestyle of the people, is connected to in-depth values of the community. This may be considered as the relationship of the tradition to the morals and ethics of the people, which is symbolic.

The dish represents the Batangueño culinary tradition which uses locally produced products such as pork and beef meat, eggs and other poultry products, miki noodles and cassava starch. This makes raw ingredients and products accessible to the users 
and supports local produce provided by the province. Another importance of the dish that connects it to Batangas culinary culture is its simplicity and the tradition of slow cooking: It is simple because it focuses on easily attainable ingredients that involve little preparation and an uncomplicated cooking process. It is also important to highlight the natural flavours and taste provided by the different ingredients used, especially pork. It promotes slow cooking tradition because of the need to cook caldo. It must be cooked in a low heat to extract more flavour of pork from the bones. This also contributes to the natural taste needed in the dish.

From an acculturated food from the Chinese, now it is being used for social empowerment and development to alleviate poverty. Lomi is now a food product that can create a lot of opportunities and changes for people who are investing in this. The primary highlighted consequence of getting involved in this industry, for both the owners and employees of the lomi houses, is the ability to finance the education of their children. Many start to work for this industry because they wanted to provide better life opportunities for their family, especially their children.

Lomi provides the venue for social interaction, family togetherness and religious equality. For most people, every weekend is a family day and with lomi, they get the chance to bond with their family members, relatives and friends. Eating lomi in a lomian or cooking it in their own home is one way of using their time during those days. With this dish, religious equality is also promoted especially in terms of dietarybased requirements for some of the religious sectors like for Muslims and Adventists. Lomi houses are now providing new kinds of lomi that do not contain pork; instead, they are using chicken and beef.

\section{Kusinero (Chef): Stakeholders' Perspective on the Culinary Tradition of Lomi based on the Focus Group Discussion (FGD)}

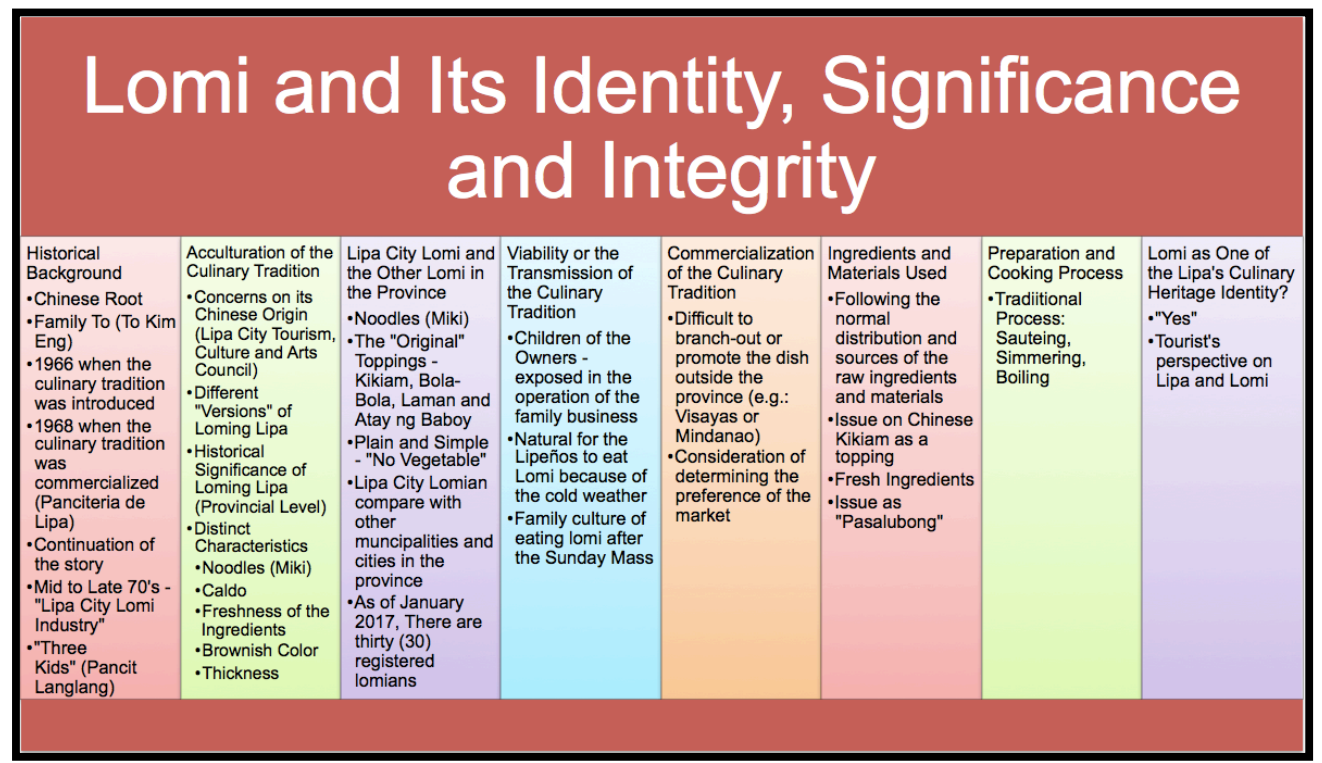

Fig 4. Representation of the FGD findings for the first sub-topic: Lomi and its identity, significance and integrity 
First of all, it was highlighted that the Chinese migrant To Kim Eng from Amoy (now Xiamen), China, introduced lomi, initially serving the dish as an afternoon snack to his group of friends who were playing mahjong. They decided to have only one member from the group to cook food because of the intensity of the game that could disrupt the eating schedule or habit of the players. It was To Kim Eng who volunteered to do the task as he knew how to cook. He decided to cook noodle-based dishes and one of them was lomi. It was in 1966 when he first made lomi and by 1968, lomi was introduced to the community as a commercialized dish. This was when the restaurant Panciteria de Lipa was established, located at Barangay Poblacion 4 of Lipa City.

When it comes to the acculturation of lomi, it was discussed that the stakeholders' major concern is the Chinese origin of the dish, which was pointed out by the Lipa City Tourism, Arts and Culture Council (LCTACC). They wanted to highlight culinary identities of the city that has its local Lipeño trademark either to the ingredients, to the process of cooking or the taste of the dish.

It is also important to determine the difference of Lipa lomi from the others. The distinctiveness of the Lipa lomi is based on the miki used, the original toppings used such as kikiam, bola-bola, laman (meat) and atay (liver) of the pig; and the characteristics of being plain and simple since there was no vegetable added to it.

When it comes to the viability or the transmission of the culinary tradition, there are three (3) aspects that were emphasized: First, lomi house owners trained their own children by giving them responsibilities and tasks in the operation of their business. Another aspect is the impact of cold weather conditions in the city, which urged the people to eat lomi and other hot soup or food to make them comfortable. Lastly, every Sunday after attending Holy Mass, families would visit lomi houses to eat lomi.

Another factor that was discussed is about the commercialization of the culinary tradition, not only in the city or province but also the possibility of extending it outside the province. It was pointed out by lomi house owners that it is difficult to market it outside the province, especially regarding branching out or franchising the business.

The ingredients and materials used for lomi were also discussed. Most of the ingredients and materials used for lomi are available at the Lipa City Public Market. All the raw ingredients and materials are transported to the public market yet are produced in other places. Another point that was highlighted is the kikiam as a component. LCTACC considers it as a big issue because it contributes to the dish's Chinese origin. The freshness of raw ingredients is encouraged for all lomi houses to be observed at all times because it contributes to the richness of the flavour of each ingredient. Lastly, the issue for encouraging people to buy lomi as pasalubong (souvenir) after visiting the city was addressed through the conceptualization of a plan of including it as one of the products for a centralized souvenir center that will be funded and managed by the LCTACC and the local government. 
Stakeholders agreed that the process of cooking lomi remains the same to this day: sautéing the basic aromatics like garlic and onions together with the meat and/or internal organs of an animal; adding the condiments to provide the desired taste like soy sauce; pouring the caldo or water as the base soup until it simmers; adding the miki until it slightly cooks; beating an egg and incorporating it to the soup; and lastly adding the slurry, which is a combination of cassava starch and water. Lastly, the stakeholders were asked if lomi could be considered as one Lipa's culinary identities. All of them agreed.

\section{Lomi, Culinary Issues and Constraints}

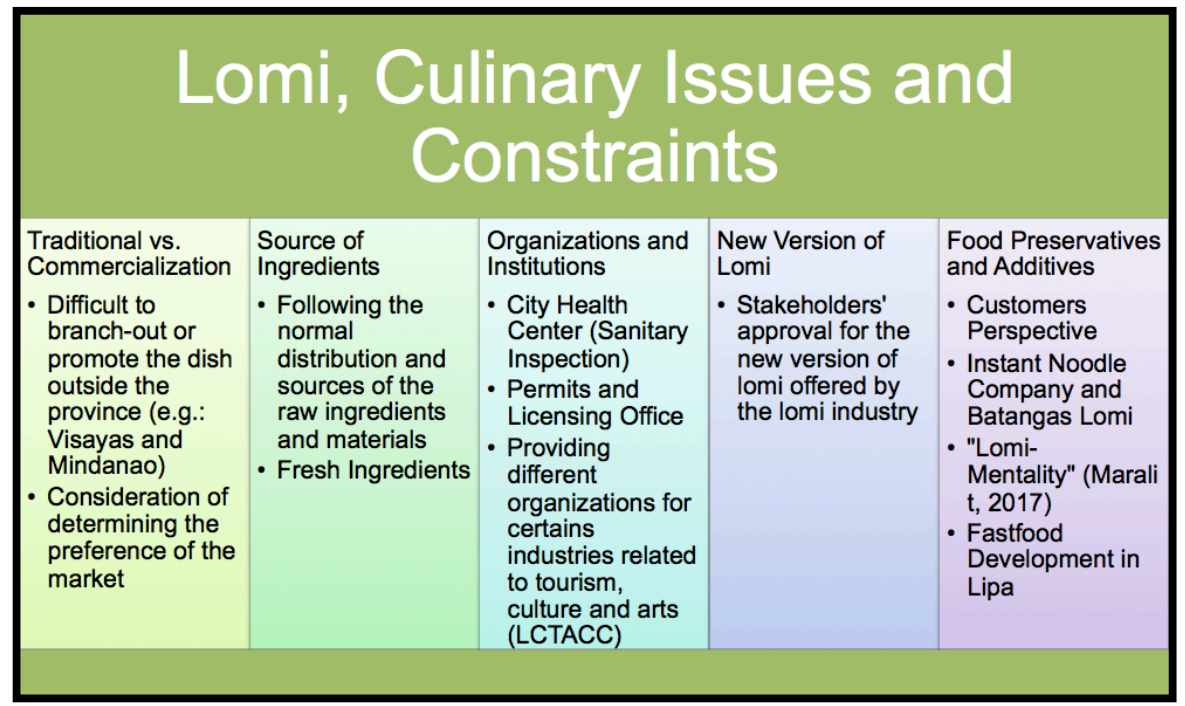

Fig 5. Representation of the FGD findings for the second sub-topic: Lomi, culinary issues and constraints

As it was discussed from the first subtopic, commercialization of the culinary tradition is met with various obstacles, especially if it will be offered outside the province due to the differences in the environment and climate, as well as the taste and ingredients preferred by the potential market. When it comes to the sources and production of the raw ingredients, in the stakeholders' perspective, it is already normal for them to gather raw ingredients from different areas. However, the most important characteristic is to use fresh ingredients for lomi, be they the soup base, the noodles or the toppings.

As lomi is being commercialized in the city by means of establishing lomi houses or restaurants, the local government under the jurisdiction of the City Health Center and the Permits and Licensing Office supervises them for certain aspects. When it comes to an organization or institution that will oversee the conservation and preservation of the culinary tradition, the LCTACC pointed out that they plan to have different specialized organizations for each specific industry who will supervise and manage any concerns and issues within their group.

New versions of lomi are still being practised in the city and even in other places in the province. It is particularly common for commercialization to be implemented in the culinary tradition: Lomi is being used as a business product, and to make each 
business establishment unique, they execute product innovation and enhancement. From the stakeholders' perspective, it is especially important that the customers or the potential market accept and be satisfied with the experience of the culinary tradition. These will provide more opportunities and choices for the customers on where and why to eat.

Lastly, the issue on food preservation and additives were discussed. This is all about the emergence of using different food flavour enhancement such as monosodium glutamate or also known as Vetsin. According to the stakeholders, the customers have the final say on how to deal with this issue. These ingredients could make the food more flavourful and could enhance the richness and even the appearance of the dish. In reality, they could lead to different illnesses, diseases and sickness on the part of the consumers. Another topic was about the development of an instant lomi noodle, which was promoted as the Batangas Lomi. The stakeholders also highlighted the term "lomi-mentality", which can be explained using three (3) Filipino words: mura (cheap), masarap (delicious) and nakakabusog (can satisfy hunger). The lomi culinary tradition and commercialization have also changed because of the existence of fast food establishments in the city. The preferences of the new generation (or also known as the millennials) are now modernized or based on the current trend on food and beverages. This is observed especially on the usage of food preservatives and additives (e.g.: the use of bouillon cubes instead of the traditional broth), process of cooking (e.g.: the use of pressure cooker) and presentation and consumption (e.g.: the use of sizzling plate instead of the traditional bowl).

Conservation and Sustainable Development of Lomi's Culinary Heritage Significance From the previous years, there were two (2) non-governmental organizations (NGOs) that were responsible for Lipa City's heritage and culture. These were the Lipa City Culture and Arts Council (LCCAC) and the Lipa City Tourism and Museum Council (LCTMC). At present, the two NGOs have been merged together, now known as the LCTACC. The problem regarding the attachment of the Council to the local government unit (LGU) as a de facto organization is still unresolved. It remains as an NGO but its funds and financial support are coming from an appropriation from the LGU.

\begin{tabular}{|c|c|c|c|}
\hline \multicolumn{4}{|c|}{$\begin{array}{c}\text { Conservation and Sustainable Development } \\
\text { of Lomi's Culinary Heritage Significance }\end{array}$} \\
\hline $\begin{array}{l}\text { Organizations and } \\
\text { Institutions } \\
\text { - Conflict between the } \\
\text { Culture and Arts; and } \\
\text { Tourism and Museum } \\
\text { Councils } \\
\text { - Tourism, Arts and } \\
\text { Culture Council as a } \\
\text { "de-facto" NGO } \\
\text { - Plans for Lipa City } \\
\text { Tourism Office as part } \\
\text { of the LGU }\end{array}$ & $\begin{array}{l}\text { Current and } \\
\text { Proposed Plans } \\
\text { and Projects } \\
\text { - Promotions } \\
\text { - Festivals } \\
\text { - Issue on Lomi Festival } \\
\text { - Legislative } \\
\text { Measurements } \\
\text { - Accreditation of } \\
\text { Tourism } \\
\text { Establishments } \\
\text { - Pasalubong Center }\end{array}$ & $\begin{array}{l}\text { Integration } \\
\text { - Environmental } \\
\text { Conservation } \\
\text { - Policy and } \\
\text { Governance } \\
\text { - Social Development } \\
\text { - Health and Wellness } \\
\text { - Disaster Management } \\
\text { - Religious Tradition } \\
\text { - Education }\end{array}$ & $\begin{array}{l}\text { Final Perspectives } \\
\text { of the } \\
\text { Stakeholders } \\
\text { - Office of the City } \\
\text { Planning and } \\
\text { Development } \\
\text { Coordinator } \\
\text { - Permits and Licensing } \\
\text { Office } \\
\text { - Lipa City Tourism, Arts } \\
\text { and Culture Council } \\
\text { - Private Sector (Lomi } \\
\text { Industry) }\end{array}$ \\
\hline
\end{tabular}

Fig 6. Representation of the FGD findings for the third sub-topic: Conservation and sustainable development of Lomi's culinary heritage significance 
The LCTACC is highlighting the need for comprehensive promotional strategies, which are not only focused on one tourism resource but encompass everything in the city. Another need of the Council is to come up with a festival that will highlight the city in all aspects.

There is also a plan from the LCTACC to have an official accreditation process for different tourism establishments and facilities in the city, which will provide and evaluate the standards of the establishments when it comes to the products and services offered to guests and tourists. Another plan is to have a centralized pasalubong (souvenir) centre that will showcase different local products of the city. Meanwhile, the private sector is concerned about increased competition in the city especially on the presence of franchised restaurants from Metro Manila. However, it was pointed out by LCTACC that obtaining accreditation would help the private sector.

For environmental conservation, especially when it comes to the raw ingredients, it is normal for them to be produced in other places for cost efficiency and effectiveness. But the local government is making different programs on how to develop and sustain the agriculture industry of the city to support the needs on local produce and ingredients. When it comes to social development, it is affirmative that the tradition is used as a source of livelihood by some Lipeños and which has become a unique sector of Lipa's food and beverage industry. Health and wellness is an important aspect of the society. Even though lomi is delicious and rich in flavour, according to some gastrologists and orthologists in the city, there are two local dishes that can increase the risk for gout and uric acid: gotong Lipa (Lipa's beef internal organ soup) and lomi. Aside from that, lomi is high in cholesterol, which can lead to high blood pressure and an increase in bad cholesterol. The negative health effects to which the dish can contribute is something that lomi restaurant owners have to tackle.

At present, owners of lomi houses are participating in relief operations and feeding programmes, providing food such as lomi during natural calamities in the province. For the religious tradition, the lomi house industry has already adjusted to the dietary requirements of some religious sectors in the city, such as Muslims and Adventists, by introducing beef and chicken lomi. For the stock, they only use water instead of the traditional caldo. Lastly, all stakeholders wanted to integrate Lipa City Heritage and Culture to all lesson plans and curricula of the students and learners in the city. This can assure the sustainability of the tradition and customs of the Lipeños from one generation to the next.

\section{Kain Tayo! (Let us eat!): Results from the Quantitative Method}

\section{Background of the Respondents}

From a total of 22,731 population of Barangay 1-11 (including 9-A), 396 respondents were surveyed as the sample sizecomputed through Slovin's formula with 5\% margin of error. When it comes to the distribution of the respondents based on gender, females were the highest with two hundred thirteen (213) respondents or fifty-four per cent $(54 \%)$ of the sample size. For the respondents' age, forty per cent $(40 \%)$ or one hundred fifty-seven (157) were below eighteen years old, which represents the 
millennial generation. For the respondents' civil status, two hundred thirty-four (234) respondents or fifty-nine per cent (59\%) were single. For the respondents' highest educational attainment, forty-five per cent $(45 \%)$ or one hundred seventy-seven (177) respondents finished elementary school. Lastly, for the respondents' occupational background, forty-six per cent (46\%) or one hundred eighty-three (183) respondents were still students.

\begin{tabular}{|c|c|c|c|}
\hline $\begin{array}{l}\text { Background of the } \\
\text { Respondents }\end{array}$ & Elaborative Details & Raw Score & $\begin{array}{c}\text { Percentage } \\
\text { Distribution (\%) }\end{array}$ \\
\hline \multirow{2}{*}{ Gender } & Male & 183 & 46 \\
\hline & Female & 213 & 54 \\
\hline \multirow{5}{*}{ Age } & Below 18 years old & 157 & 40 \\
\hline & 18 to 30 years old & 64 & 16 \\
\hline & 31 to 40 years old & 58 & 15 \\
\hline & 41 to 59 years old & 95 & 24 \\
\hline & $\begin{array}{l}60 \text { years old and } \\
\text { above }\end{array}$ & 22 & 6 \\
\hline \multirow{4}{*}{ Civil Status } & Single & 234 & 59 \\
\hline & Married & 147 & 37 \\
\hline & Separated & 5 & 1 \\
\hline & Widowed & 10 & 3 \\
\hline \multirow{5}{*}{$\begin{array}{l}\text { Highest Educational } \\
\text { Attainment }\end{array}$} & Elementary school & 177 & 45 \\
\hline & High school & 96 & 24 \\
\hline & Vocational school & 28 & 7 \\
\hline & Bachelor's degree & 80 & 20 \\
\hline & Graduate degree & 15 & 4 \\
\hline \multirow{6}{*}{ Occupation } & Student & 183 & 46 \\
\hline & Blue-collar Jobs & 40 & 10 \\
\hline & White-collar Jobs & 70 & 18 \\
\hline & Unemployed & 8 & 2 \\
\hline & $\begin{array}{l}\text { Still looking for a } \\
\text { Job }\end{array}$ & 52 & 13 \\
\hline & $\begin{array}{l}\text { Others: (Self- } \\
\text { employed) }\end{array}$ & 43 & 11 \\
\hline
\end{tabular}

Table 2. Summary of the background of the respondents highlighting the highest in the preferred choices

Analysis from the Quantitative Result

For most of the respondents who answered the survey questionnaire, three hundred ninety-four (394) respondents or ninety-nine per cent (99\%) had already tried eating lomi. It was important to know if the respondents had already eaten Lipa City lomi because it would justify the results of the survey, make it more reliable and determine that the people surveyed are relevant and able to effectively provide factual and related information.

The respondents also signify the importance of determining the basic characteristics and components of Lipa City's lomi. Three hundred seventy-eight (378) respondents or ninety-five per cent (95\%) said that Lipa lomi has its distinctive colour compared 
to other lomi offerings in other areas. Three hundred eighty-nine (389) respondents or ninety-eight per cent (98\%) said that thelomi dish has a noodle component to it. Three hundred seventy-seven (377) or ninety-five per cent (95\%) of the respondents agreed that the soup of lomi is thick in its consistency. One hundred eighty-five (185) respondents or forty-seven per cent (47\%) said that Lipa lomi contains vegetables. The vegetable criteria in the questionnaire obtained the lowest number of respondents who did not see vegetable ingredients as part of the culinary tradition. Having a specific meat component of Lipa lomi gathered three hundred seventy-six (376) respondents or ninety-five per cent $(95 \%)$ while one hundred ninety-eight (198) respondents or fifty per cent $(50 \%)$ agreed that lomi has a seafood component. Three hundred eighty-three (383) respondents or ninety-seven per cent (97\%) experienced eating lomi with its specific toppings. Three hundred eighty-four (384) respondents or ninety-seven per cent (97\%) agreed that in eating lomi, there must be a sauce to complement it. For the egg component of the noodle soup, all respondents agreed that it is always part of the dish especially mixed in the soup. Lastly, three hundred eightyfive (385) respondents or ninety-seven per cent (97\%) agreed that there must be different serving utensils being included that are used during the consumption of the noodle soup.

\begin{tabular}{|c|c|c|c|}
\hline $\begin{array}{c}\text { Basic } \\
\text { Characteristics }\end{array}$ & $\begin{array}{l}\text { Choices of the } \\
\text { Respondents }\end{array}$ & Raw Score & $\begin{array}{c}\text { Percentage } \\
\text { Distribution (\%) }\end{array}$ \\
\hline \multirow{3}{*}{ Colour } & $\begin{array}{l}\text { Brown to Dark } \\
\text { Brown }\end{array}$ & 195 & 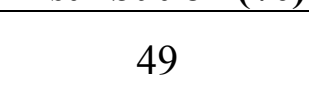 \\
\hline & Yellowish & 197 & 50 \\
\hline & Others & 3 & .75 \\
\hline \multirow{4}{*}{ Noodle types } & Thick Miki Noodles & 278 & 70 \\
\hline & Thin Miki Noodles & 89 & 22 \\
\hline & Flat Miki Noodles & 8 & 2 \\
\hline & Others & 2 & .50 \\
\hline \multirow{4}{*}{ Thickening Agent } & Cassava Starch & 317 & 80 \\
\hline & Cornstarch & 36 & 9 \\
\hline & Flour & 29 & 7 \\
\hline & Others & 2 & .50 \\
\hline \multirow{5}{*}{ Vegetable (if added) } & Carrot & 119 & 30 \\
\hline & Cabbage & 121 & 31 \\
\hline & Baguio Beans & 42 & 11 \\
\hline & Onion/Garlic & 3 & .75 \\
\hline & Others & 2 & .50 \\
\hline \multirow{3}{*}{ Meat } & Pork & 331 & 84 \\
\hline & Beef & 32 & 8 \\
\hline & Chicken & 53 & 13 \\
\hline \multirow{4}{*}{ Seafood (if added) } & Shrimp & 174 & 44 \\
\hline & Squid & 61 & 16 \\
\hline & Mussels & 13 & 3 \\
\hline & Others & 2 & .50 \\
\hline \multirow[t]{2}{*}{ Toppings } & $\begin{array}{c}\text { Chinese or } \\
\text { Homemade Kikiam }\end{array}$ & 318 & 80 \\
\hline & Squid Ball & 158 & 40 \\
\hline
\end{tabular}




\begin{tabular}{|c|c|c|c|}
\hline & Fish Ball & 91 & 23 \\
\hline & Pork Liver & 294 & 74 \\
\hline & Crispy Fried Pork & 227 & 57 \\
\hline & Egg & 2 & .50 \\
\hline & Bola-Bola & 5 & 1 \\
\hline & Chicken & 1 & .25 \\
\hline & Toasted Garlic & 1 & .25 \\
\hline & Others & 3 & .75 \\
\hline \multirow{6}{*}{ Sauce } & Soy Sauce & 369 & 93 \\
\hline & Calamansi & 324 & 82 \\
\hline & Bird's Eye Chilli & 229 & 58 \\
\hline & Onions & 281 & 71 \\
\hline & Garlic & 1 & .25 \\
\hline & Others & 1 & .25 \\
\hline Poultry Product & Egg & 396 & 100 \\
\hline \multirow{6}{*}{$\begin{array}{l}\text { Serving Material / } \\
\text { Utensil }\end{array}$} & Soup Bowl & 365 & 92 \\
\hline & Plate & 202 & 51 \\
\hline & Spoon & 308 & 78 \\
\hline & Fork & 288 & 73 \\
\hline & Sizzling Plate & 11 & 3 \\
\hline & Chopsticks & 8 & 2 \\
\hline
\end{tabular}

Table 3. Specific characteristics and components of Lipa City's lomi based on the respondents' perspective

In Table 3, it shows the specific characteristics and components of Lipa City's lomi from the respondents' perspective. The highlighted parts gained the highest number of respondents. This shows the similarities of opinions and experiences of the respondents on Lipa City's lomi culinary tradition.

When it comes to the respondents' perspective on the importance of lomi for the city and for the local community, all respondents said that lomi culinary culture is important for the city and for them as the local community.

\begin{tabular}{|l|c|c|}
\hline $\begin{array}{c}\text { Lomi Culinary Heritage } \\
\text { Significance }\end{array}$ & Raw Score & $\begin{array}{c}\text { Percentage } \\
\text { Distribution } \\
(\mathbf{\%})\end{array}$ \\
\hline Historical Significance & 218 & 55 \\
\hline Economic Significance & 183 & 46 \\
\hline Cultural Significance & $\mathbf{2 3 8}$ & $\mathbf{6 0}$ \\
\hline Social Significance & 151 & 38 \\
\hline Symbolical Significance & 80 & 20 \\
\hline $\begin{array}{l}\text { Others: Normal Culinary } \\
\text { Practice, Nutritional and } \\
\text { Source of Food) }\end{array}$ & 4 & 1 \\
\hline
\end{tabular}

Table 4. Summary of the results regarding the respondents' perspective on the determination of culinary heritage significance of lomi in Lipa City 
Table 4 (above) shows the results of the survey in determining the culinary heritage significance. Two hundred thirty-eight (238) respondents or sixty per cent (60\%) said that lomi has cultural significance, which indicates the importance of lomi as one of their culinary traditions. This also garnered the highest number of respondents from the survey. As for Table 5 (below), it shows the summary of results for the area level of lomi culinary heritage significance. One hundred sixty-nine (169) respondents or forty-three per cent (43\%) said that lomi has provincial significance as it is important in the province of Batangas. The provincial level got the highest number of respondents, highlighted in yellow.

\begin{tabular}{|l|c|c|}
\hline $\begin{array}{l}\text { Area Level of Lomi Culinary } \\
\text { Heritage Significance }\end{array}$ & Raw Score & $\begin{array}{c}\text { Percentage } \\
\text { Distribution } \\
(\%)\end{array}$ \\
\hline $\begin{array}{l}\text { Barangay (Small Community- } \\
\text { level) }\end{array}$ & 70 & 18 \\
\hline Local (City-level) & 102 & 26 \\
\hline Provincial & 169 & 43 \\
\hline Regional & 63 & 16 \\
\hline National & 115 & 29 \\
\hline International & 23 & 6 \\
\hline
\end{tabular}

Table 5. Summary of the results regarding the respondents' perspective on the level or scope of significance for lomi in Lipa City

It is also important to determine the perspectives of the respondents on sustainability, information dissemination, viability, enhancement and recommendations to safeguard and develop lomi as a culinary identity of Lipa City. (Note: For the succeeding discussion, the following were also obtained from the survey but not placed in a table.)

When it comes to the respondents' perspective on the sustainability of lomi culinary tradition in the city, all respondents said that Lipa lomi must be conserved, protected and continuously practised as a culinary tradition especially in the context of cooking, preparing and eating. For the reason of sustaining the culinary tradition, two hundred ninety-eight (298) respondents or seventy-five per cent (75\%) said that lomi is already a tradition of the local community.

For the respondents' perspective on disseminating lomi culinary tradition, three hundred ninety (390) respondents or ninety-eight per cent (98\%) said that the culinary tradition of cooking, preparing and eating lomi in Lipa should be disseminated and transmitted especially to the younger generation. In transmitting and inculcating the culinary tradition to the next generation, two hundred ninety-four (294) respondents or seventy-four per cent (74\%) agreed that it would be better to introduce lomi as a breakfast dish or a snack.

For the respondents' perspective on the changes in lomi culinary tradition, sixty-eight per cent $(68 \%)$ or two hundred sixty-eight (268) respondents said that they are open to some changes in the details of the culinary tradition of cooking, preparing and eating 
lomi in Lipa, such as the ingredients used, materials needed, the process of cooking, the way of eating and the like. For the commercialization of the culinary tradition within or outside the province of Batangas, ninety-eight per cent $(98 \%)$ or three hundred ninety (390) respondents are agreed the commercialization of Lipa lomi within and outside the context of the city.

Lastly, for potential recommendations of the respondents when it comes to the safeguarding and sustainable development of the culinary tradition, two hundred nineteen (219) respondents or fifty-five per cent (55\%) said that proper research and documentation must be done especially for the recipe and the cooking process. One hundred fifty-one (151) respondents or thirty-eight per cent (38\%) said that the Department of Education (DepEd) Division in Lipa must integrate the culinary tradition to school curricula. The integration of the culinary tradition must also be implemented to higher education especially for BS Hotel and Restaurant Management, and BS Tourism Management programmes. One hundred fifty-four (154) respondents or thirty-nine per cent (39\%) said that heritage interpretation such as integrating the culinary tradition to the current museum narrative of Lipa must be implemented. One hundred sixty-nine (169) respondents or forty-three per cent (43\%) said that publishing different books and articles related to the culinary tradition could be implemented to properly disseminate information. Two hundred twenty (220) respondents or fifty-six per cent $(56 \%)$ said that workshops and trainings could be given to those people who wanted to learn the culinary tradition and even use it for economic purposes. One hundred seven (107) respondents or twenty-seven per cent $(27 \%)$ said that it is a must to have a constructive organization for owners of the lomi houses and related businesses so that the industry can be properly regulated. One hundred sixty-three (163) or forty-one per cent (41\%) respondents said that the local government unit and even the private sector must provide different promotional resource materials such as videos, flyers and brochures related to the culinary tradition. Garnering the highest number of respondents, providing tourism programmes received two hundred thirty-three (233) respondents or fifty-nine per cent $(59 \%)$ of the total respondents. The local community is already aware of the importance of lomi as a tourism attraction. It is better to provide different programmes and projects to develop it as a standardized culinary attraction. Four (4) respondents or one per cent $(1 \%)$ said that there are other forms of programmes that can be implemented to continuously conserve and develop the culinary tradition. 


\section{Conclusion and Recommendations}

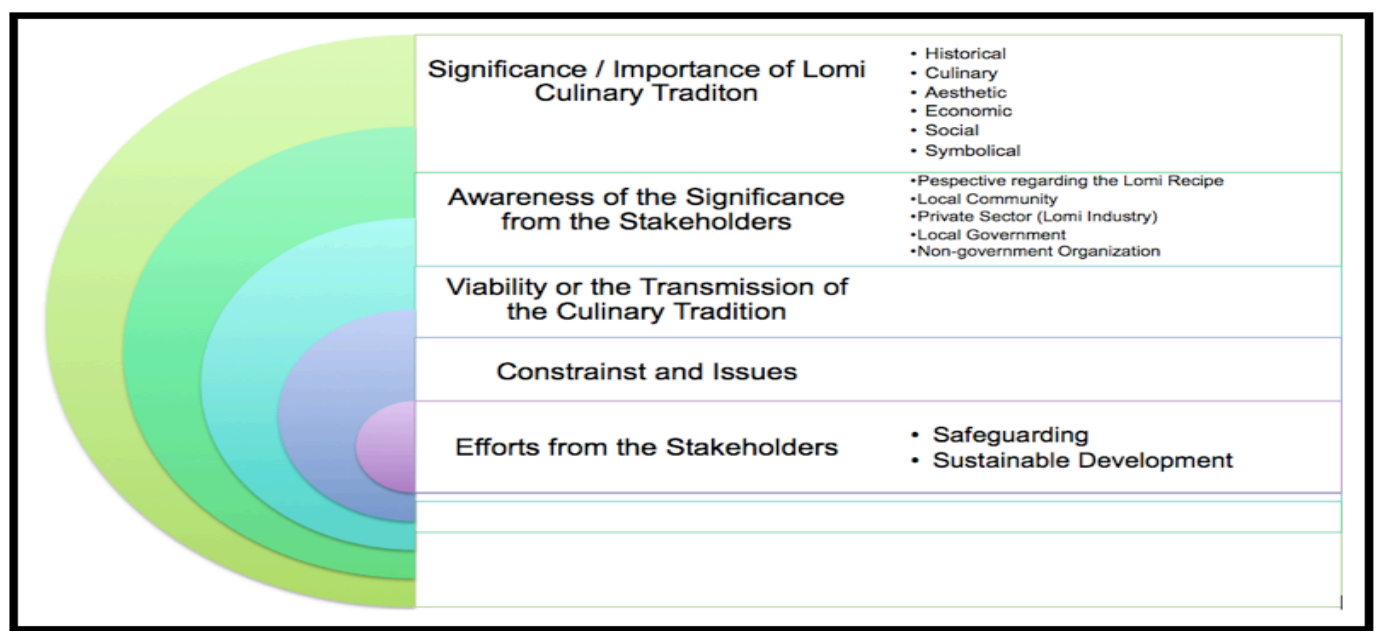

Fig 7. Representation of the researcher's conclusion

Figure 7 shows a representation of the researcher's conclusion for the paper. As the most important content of the paper, the significance or importance of lomi culinary tradition was highlighted. As the culinary tradition is already available in the area, the context of awareness of the different stakeholders is also included. The discussion is focused on the commonality of the perspectives related to the culinary tradition as a dish and the degree of awareness. As culinary tradition is considered as an intangible cultural heritage under the 2003 UNESCO Convention for the Safeguarding of the Intangible Cultural Heritage, it is also important to determine the viability concept of the culinary tradition or the transmission of the tradition from generation to generation. And as it continues to be practised, there are certain issues and constraints that may emerge or be experienced which can lead to either the degradation or sustainability of the culinary tradition. Lastly, a discussion of the stakeholder's effort to diminish the negative aspects and effects of the culinary tradition and to sustainably safeguard and develop it was determined.

\begin{tabular}{|c|c|c|}
\hline \multirow{2}{*}{ Characteristic } & \multicolumn{2}{|c|}{ Perspectives } \\
\hline & Lomi Industry & Local Community \\
\hline $\begin{array}{l}\text { Raw Ingredients and } \\
\text { Components }\end{array}$ & $\begin{array}{l}\text { - Sautéing Agent-Oil, } \\
\text { Garlic and Onion } \\
\text { - } \quad \text { Animal Meat and } \\
\text { Internal Organ- } \\
\text { Pork Meat and Liver } \\
\text { - Seafood*-Shrimp } \\
\text { and Squid } \\
\text { - Taste or Seasoning } \\
\text { Agent - Soy sauce } \\
\text { - Stock-Caldo (Pork- } \\
\text { based) }\end{array}$ & $\begin{array}{l}\text { - Sautéing Agent-Oil, } \\
\text { Garlic and Onion } \\
\text { - Animal Meat and } \\
\text { Internal Organ-- } \\
\text { Pork Meat and Liver } \\
\text { - Seafood-Shrimp and } \\
\text { Squid } \\
\text { - Taste or Seasoning } \\
\text { Agent-Soy sauce } \\
\text { - Stock-Caldo (Pork- } \\
\text { based) }\end{array}$ \\
\hline
\end{tabular}




\begin{tabular}{|c|c|c|}
\hline & $\begin{array}{ll}\text { - } & \text { Noodle - Miki } \\
\text { - } & \text { Thickening Agent- } \\
\text { Cassava Starch } \\
\text { - } \quad \text { Vegetable* - } \\
\text { Cabbage and Carrot } \\
\text { - Other - Chicken Egg } \\
\text { - } \quad \text { Basic Toppings - } \\
\text { Kikiam, Bola-Bola, } \\
\text { Pork Meat and Liver } \\
\text { - Sauce - Soy sauce, } \\
\text { Calamansi, Bird's } \\
\text { Eye Chilli and Onion } \\
\text { - All ingredients must } \\
\text { be fresh. }\end{array}$ & $\begin{array}{ll}\text { - } & \text { Noodle - Miki } \\
\text { - } & \text { Thickening Agent - } \\
\text { Cassava Starch } \\
\text { - } \quad \text { Vegetable - Cabbage } \\
\text { and Carrot } \\
\text { - Other - Chicken Egg } \\
\text { - } \quad \text { Basic Toppings - } \\
\text { Kikiam, Pork Liver, } \\
\text { Crispy Fried Pork, } \\
\text { Squid Ball and Fish } \\
\text { Ball } \\
\text { - Sauce - Soy sauce, } \\
\text { Calamansi, Bird's } \\
\text { Eye Chilli and Onion }\end{array}$ \\
\hline Colour & $\begin{array}{l}\text { Yellowish to Brown and } \\
\text { Dark Brown }\end{array}$ & Yellowish \\
\hline Consistency & Thick & Thick \\
\hline $\begin{array}{l}\text { Cooking Materials and } \\
\text { Utensils }\end{array}$ & $\begin{array}{ll}\text { - } & \text { Bowl } \\
\text { - } & \text { Plate } \\
\text { - } & \text { Spoon } \\
\text { - } & \text { Fork } \\
\text { - } & \text { Saucer }\end{array}$ & $\begin{array}{ll}\text { - } & \text { Bowl } \\
\text { - } & \text { Plate } \\
\text { - } & \text { Spoon } \\
\text { - } & \text { Fork } \\
\text { - } & \text { Saucer }\end{array}$ \\
\hline Process of Cooking & $\begin{array}{ll}\text { - } & \text { Sautéing } \\
\text { - } & \text { Simmering } \\
\text { - } & \text { Quick-boiling to } \\
& \text { Boiling } \\
\end{array}$ & $\begin{array}{l}\text { - Sautéing } \\
\text { - Simmering } \\
\text { - } \text { Boiling }\end{array}$ \\
\hline Food Presentation & $\begin{array}{l}\text { Lomi is placed in a bowl, } \\
\text { topped with a specific } \\
\text { topping and served with } \\
\text { chopped onions and } \\
\text { bird's eye chilli as part of } \\
\text { the sauce. }\end{array}$ & $\begin{array}{l}\text { Lomi is placed in a bowl, } \\
\text { topped with a specific } \\
\text { topping and served with } \\
\text { chopped onions and } \\
\text { bird's eye chilli as part of } \\
\text { the sauce. }\end{array}$ \\
\hline \multirow{2}{*}{ Identity } & \multicolumn{2}{|c|}{$\begin{array}{c}\text { Perspectives } \\
\end{array}$} \\
\hline & Lomi Industry & Local Community \\
\hline $\begin{array}{l}\text { Reason for Sustaining the } \\
\text { Culinary Tradition }\end{array}$ & Source of income & Lifestyle and tradition \\
\hline $\begin{array}{l}\text { Disseminating the } \\
\text { Culinary Tradition? }\end{array}$ & Yes & Yes \\
\hline $\begin{array}{l}\text { Changes Implemented in } \\
\text { the Culinary Tradition? }\end{array}$ & Yes & Yes \\
\hline $\begin{array}{l}\text { Commercialization of the } \\
\text { Culinary Tradition? }\end{array}$ & $\begin{array}{l}\text { Yes but as much as } \\
\text { possible, it must be } \\
\text { within the province }\end{array}$ & Yes \\
\hline
\end{tabular}

Table 6. Comparison of perspectives on Lipa lomi's characteristics and identity based from the perspectives of the lomi industry practices and local community. * indicates not all lomi houses are practising or incorporating these components 
Table 6 shows a comparative analysis of the perspectives between the local community and the lomi industry when it comes to Lipa lomi's characteristics and identity. When it comes to the raw ingredients and its components, most of the items are the same for both parties. But there are certain details that are not being practised by the lomi industry; for instance, the incorporation of seafood and vegetable to the dish. When it comes to seafood, it is far expensive to include in the dish compared with other meat ingredients. But to adjust with the preference of the local community regarding seafood, lomi houses have incorporated fish balls and squid balls as alternative ingredients. Another adjustment implemented by the lomi houses is incorporating deep fried crispy pork as a topping instead of sautéed or boiled pork meat.

When it comes to the colour of the dish, both parties agreed that it is brown to dark brown. But the local community also highlighted that it is yellowish in colour because of the colour of the miki noodles used. For other characteristics such as consistency, cooking utensils and materials used, process of cooking and food presentation, the table also shows that the lomi industry and the local community agreed with the same characteristics.

When it comes to the reasons for sustaining the culinary tradition, for the lomi industry, it is a source of income, while for the local community, it is part of the lifestyle or tradition. For the dissemination, implementation of changes and innovation, and commercialization of the culinary tradition, both parties agreed for an affirmative response that all characteristics can be done and practised.

From the perspective of stakeholders, specifically the lomi house owners, local community, local government unit and non-government organization, lomi culinary heritage is important for the city and its community as a culinary tradition, a socioeconomic development tool and the city's identity for culinary tourism. Another perspective is about "lomi-mentality", which describes the identity and significance of the dish. Based on the perspective of the local community, the culinary tradition is significant in its cultural identity and historical, economic, social and symbolic value. When it comes to the scope of its significance, Lipa lomi is important in the provincial entity (Batangas), as it is observed that lomi louses are spread throughout the province.

When it comes to lomi as one of the culinary traditions of the city, stakeholders from the government and non-government organizations in particular are concerned about its Chinese origin. Another issue is about the nutritional and health-related effects of eating lomi. Even though it is rich in carbohydrates and protein, the dish can increase the body's uric acid and cholesterol level. That is why if a person has high risk in terms of gout and high blood pressure problems, physicians will always advise to eat lomi moderately.

Due to the emerging trends on food preservatives and additives, most of the lomi house owners are using them to enhance the flavour of the dish and even to lessen the cost when it comes to its ingredients. For instance, instead of using pork bones for 
caldo, it can be substituted with pork bouilloin cubes and Vetsin because it is cheap and more affordable.

As a culinary attraction of the city, there is a possibility that potential tourists or customers would like to buy it as as pasalubong or souvenir. Unfortunately, because of the characteristics of the ingredients, specifically the miki noodles, it is not advisable because the noodles will absorb the soup. The noodles become soggy and over-cooked. But the owners of the lomi houses are now creating new ways on how to enhance it as a souvenir without degrading its identity and integrity.

For the lomi house owners, one of their major problems is competition faced, both direct and indirect. Because of this, product innovation emerges especially when it comes to different variations and types of lomi. Aside from the lomi houses, fast food and other food service establishment are continuously increasing due to the rapid demands of the market. Influences of other Philippine and foreign cuisines can also affect the sustainability of the culinary tradition and lomi industry. Another problem is about sufficient and effective promotional strategy other than word-of-mouth. Even though word-of-mouth is the best promotional strategy, it is also better to have other strategies that can approach larger potential market not only in the Philippines but also to other countries. Lastly, there is also a problem when it comes to the regulatory bodies that are assigned to provide, execute and maintain the standards and policies on safeguarding and sustainably developing the culinary tradition.

As lomi culinary tradition is important to the city and its community, different stakeholders are now taking their own steps on how to safeguard and sustainably develop it for the benefit of the future generation. For the local government unit, they manage to continue providing efforts on promoting the culinary tradition by including it in their general city profile documentation and promotional brochures created by the Office of the City Planning and Development Coordinator. Another programme is to continuously provide the list of registered restaurants and eateries that offer lomi as its primary or secondary menu item. The Permits and Licensing Office supervises the process and issuance of business permits, and updates the list of registered business establishment in the city. For non-governmental organizations, and the Lipa City Tourism, Arts and Culture Council in particular, they are aiming to have a permanent organic tourism office under the local government unit who will provide comprehensive promotional programmes for all tourism activities in the city; create a sustainable festival that will highlight all resources and products of the city; implement an accreditation process for different tourism-based establishments and activities; create different organizations specialized in a specific tourism sector that will be considered as their official representative and establish a pasalubong centre, which will highlight the different local products and delicacies. The Council also agrees with the implementation of integrating the cultural and heritage values of the city to the curriculum of the students and learners from basic education up to the tertiary level.

As for the lomi industry, lomi house owners assured that they would continue to maintain the quality of their own versions of lomi and safeguard the culinary tradition by sustainably transmitting and sharing it with their family members, friends and even to other people who are willing to learn about the culinary tradition. Lastly, from the 
part of the local community, based on their own observations and perspectives, they are proposing to have different programmes and projects to strengthen the lomi culinary tradition as one of the major tourism resources of the city, such as providing lomi workshops and trainings; compiling a comprehensive documentation of the culinary tradition; creating different publications on the culinary tradition such as coffee table books; making available different promotional paraphernalia such as brochures, pamphlets, leaflets and magazines which can be accessible to potential tourists and guests; providing culinary heritage interpretation like exhibitions; integrating the significance and identity of the culinary tradition to the curriculum of the students and learners; and having an organization that will provide, supervise and maintain the quality and standards of lomi houses and other related industries.

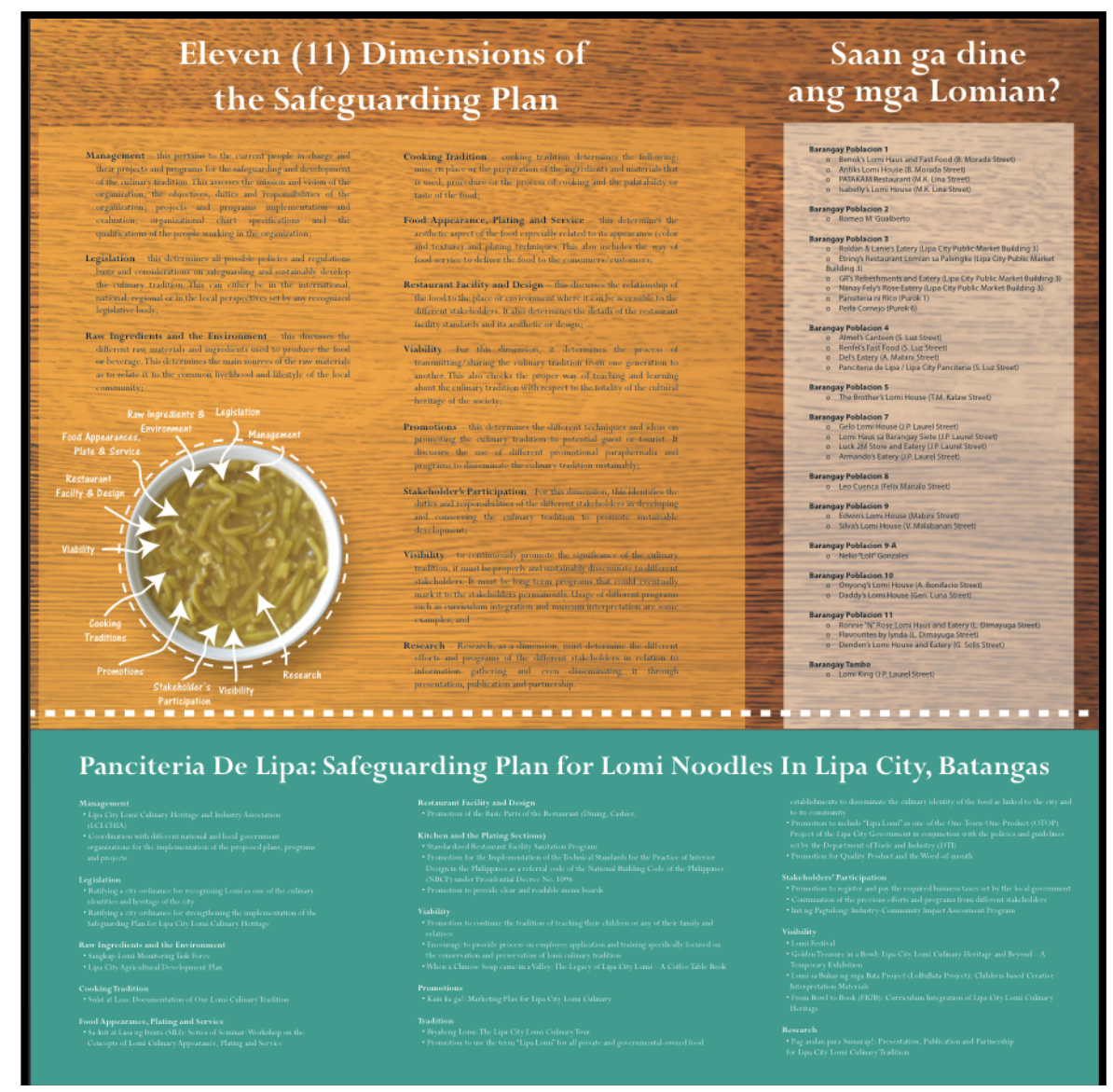

Fig 8. Panciteria de Lipa: Safeguarding plan for lomi noodles in Lipa City, Batangas. (Source: Authors)

Establishing an organization is one of the first steps to start the process. It is imperative that before planning for any projects and programmes, there must be a group of people or an institution that will manage and supervise it. The proposed Lipa City Lomi Culinary Heritage and Industry Association (LCLCHIA) will be the anchor organization responsible for the development and conservation of the lomi culinary tradition and industry in the city. This will also provide a good venue for cooperation and partnership with different stakeholders of the culinary tradition that will make it sustainable. 


\section{References}

Alejandro, J (1998) The Food of the Philippines: authentic recipes from the pearl of the Orient. Singapore: Periplus. Google Scholar search

Alejandro, R, Reyes, M \& Santos, V (2008) Fiesta! Fiesta!: Festival Foods of the Philippines. Manila: KCC Innovations, Inc. Google Scholar search

Alvina, C and Roces, M (2016) A Delicate Balance: Batanes Food, Ecology and Community. Pasig City: Museo ng Kaalamang Katutubo, Inc. Google Scholar search

Andrus, P W, Shrimpton, R H 2002. How to Evaluate the Integrity of a Property. U.S. Dept. of the Interior - National Parks Service, National Register, History and Education. Google Scholar search

ASEAN (n.d.) ASEAN Tourism Standards. Jakarta: ASEAN Secretariat. Google Scholar search

ASEAN (2014). Far-flung ASEAN Culinary Delicacies. ASEAN. Available at https://www.aseantourism.travel/articles/detail/far-flung-asean-culinarydelicacies

Australia ICOMOS (2013) The Burra Charter: The Australia ICOMOS Charter for Places of Cultural Significance. Australia: Deakin University. Google Scholar search

Barham, E (2003) Translating Terroir: The Global Challenge of French AOC Labeling. Journal of Rural Studies (19):127-138. Crossref

Bessiere, J (2013) "Heritagisation", a challenge for tourism promotion and regional development: an example of food heritage. Journal of Heritage Tourism 8(4):275-291. Crossref

Boyce, C and Neale, P (2006) Conducting In-depth Interviews: A Guide for Designing and Conducting In-depth Interviews for Evaluation Input. Watertown: Pathfinder International. Google Scholar search

Buenavente, A (2009) Kulinarya Food Trips. Department of Tourism. Available at: http://www.tourism.gov.ph/Pages/KulinaryaFoodTrips.aspx

Congress of the Philippines (2009) Republic Act No. 10066: An Act Providing for the Protection and Conservation of the National Cultural Heritage, Strengthening the National Commission for Culture and the Arts (NCCA) and its Affiliated Cultural Agencies, and for Other Purposes. Google Scholar search

Council on International Education Exchange (n.d.) Food the edible part of culture (Brochure). Portland, ME: Council on International Education Exchange. Google Scholar search

Di Mauro, M, Vanni, M, Trampetti, S, Raschi, A and Cinelli-Colombini, D (2011) Identity expressed by local food tradition. Paper presented at the first European conference on wine and food tourism, Volterra, Italy. Google Scholar search

Easterby-Smith, M, Thorpe, R \& Lowe, A (1991) Management Research: An Introduction. London: Sage Publication. Google Scholar search

Fernandez, D (1988) Culture Ingested: Notes on the Indigenization of Philippine Food. Philippine Studies 36(2): 219-232. Google Scholar search

Fernandez, D (2000) Palayok: Philippine Food through Time, On Site, In the Pot. Makati City: Bookmark, Inc. Google Scholar search

Greeley, A. (2002). Pho: The Vietnamese Addiction. Gastronomica: The Journal of Food and Culture 2(1): 80-83. Crossref 
Horng, J and Tsai, C (2012) Constructing Indicators of Culinary Tourism Strategy: An Application of Resource-based Theory. Journal of Travel and Tourism Marketing 29: 796-816. Crossref

Kivela, J and Crotts, J (2006) Tourism and gastronomy: Gastronomy's influence on how tourists experience a destination. Journal of Hospitality and Tourism Research 3: 354-377. Crossref

LeBlanc, F. (1993) Is Everything Heritage? ICOMOS Canada Bulletin 2(2): 2-3 Google Scholar search

Lee, S (2015) Malaysia: The Impact of Modernization on Ethnic Food. Paper Presented in the International Conference on Tourism and Ethnicity in ASEAN and Beyond, Chiang Mai, Thailand. Google Scholar search

Lim, J (2012) Chinese Merchants in Singapore and the China Trade, 1819-1959. Chinese Southern Diaspora Studies 5: 79-115. Google Scholar search

Lusin, C (2013) Curry, Tins and Grotesque Bodies: Food, Cultural Boundaries and Identity in Anglo-Indian Life-Writing. English Studies 94(4): 468-488. Crossref

Melchor, J (2016) Presidential Proclamation for the "Buwan ng Kulinaryang Pilipino" has finally been drafted by NCCA. Available at https://www.change.org/p/national-commission-for-culture-and-the-artspetition-for-the-preservation-of-the-philippine-culinary-heritagegastronomy/u/1767118

Michelin Guide. (2018) Breakfast Club: 5 Lor Mee Hawker Stalls Where You Mustn't Pass On The Gravy. Michelin Guide. Available at https://guide.michelin.com/sg/dining-out/breakfast-club-5-lor-mee-hawkerstalls-where-you-mustn $\% 27 \mathrm{t}$-pass-on-the-gravy/news

Mora, J (1998) Understanding multiculturalism: cultures and values. Available at: http://coe.sdsu.edu/people/jmora/CulturalValues

Palanca, C, Oshima, N and de Guzman, G (2015) My Angkong's Noodles. Mandaluyong City: Summit Publishing Co. Google Scholar search

Philippine Department of Tourism (2012) The National Tourism Development Plan 2011-2016. Manila: DOT. Google Scholar search

Polistico, E (2016) Philippine Food, Cooking, \& Dining Dictionary. Mandaluyong City: Anvil Publishing Inc. Google Scholar search

Reynolds, P (1993) Foods and Tourism: an Understanding of Sustainable Culture. Journal of Sustainable Tourism 1(1): 48-54. Crossref

Roland, M (2013) Goulash nationalism: the culinary identity of a nation. Journal of Heritage 8(2-3): 172-181. Crossref

Sta. Maria, F (2005) GAMBILA: A Preliminary Framework for the Study of Philippine Culinary History with Multidisciplinary Impact on Contemporary Social Reality. The Journal of History LI:1-4. Google Scholar search

Stovel, H. (2007) Effective Use of Authenticity and Integrity as World Heritage Qualifying Conditions. City \& Time 2 (3): 3 Available at http://www.cecibr.org/novo/revista/docs2007/CT-2007-71.pdf

Tayag, C \& Quioc, M (2012) Linamnam: Eating One's Way Around the Philippines. Mandaluyong City: Anvil Publishing, Inc. Google Scholar search

The J Paul Getty Trust (2002). Assessing the Values of Cultural Heritage: Research Report. Available at http://www.getty.edu/conservation/publications_resources/pdf_publications/p df/assessing.pdf 
Topografico de Ricardo Fe (1887) Catalogo de la exposicion general de las islas Filipinas. Alicante: Biblioteca Virtual Miguel de Cervantes. Google Scholar search

Trubek, A (2008) The Taste of Place: A Cultural Journey into Terroir. Berkeley: University of California. Google Scholar search

Trubek, A and Bowen, S (2008) Creating the Taste of Place in the United States: Can We Learn from the French? GeoJournal (73): 23-30. Crossref

UNESCO (2002) UNESCO Declaration on Cultural Diversity. Available at http://unesdoc.unesco.org/images/0012/001271/127162e.pdf

UNESCO (2003) The Convention for the Safeguarding of the Intangible Cultural Heritage. Available at https://ich.unesco.org/en/convention

UNESCO and France (2010) Nomination File No. 00437: The gastronomic meal of the French. Available at https://ich.unesco.org/en/rl/gastronomic-meal-of-thefrench-00437

UNESCO and Mexico (2010) Nomination File No. 00400: Traditional Mexican cuisine - ancestral, ongoing community culture, the Michoacan paradigm. Available at https://ich.unesco.org/en/RL/traditional-mexican-cuisineancestral-ongoing-community-culture-the-michoacan-paradigm-00400

UNESCO, Cyprus, Croatia, Spain, Greece, Italy, Morocco and Portugal (2013) Nomination File No. 00884: Mediterranean Diet. Available at https://ich.unesco.org/en/Rl/mediterranean-diet-00884

UNESCO and Japan (2013) Nomination File No. 00869: Washoku, traditional dietary cultures of Japanese, notably for the celebration of New Year. Available at https://ich.unesco.org/en/RL/washoku-traditional-dietary-cultures-of-thejapanese-notably-for-the-celebration-of-new-year-00869

UNESCO and Republic of Korea (2013) Nomination File No. 00881: Kimjang, making and sharing kimchi. Available at https://ich.unesco.org/en/RL/kimjang-making-and-sharing-kimchi-in-therepublic-of-korea-00881

UNESCO and Turkey (2013) Nomination File No. 00645: Turkish coffee culture and tradition. Available at https://ich.unesco.org/en/RL/turkish-coffee-culture-andtradition-00645

UNESCO and Armenia (2014) Nomination File No. 00985: Lavash, the preparation, meaning and appearance of traditional Armenian bread as an expression of culture. Available at https://ich.unesco.org/en/RL/lavash-the-preparationmeaning-and-appearance-of-traditional-bread-as-an-expression-of-culture-inarmenia-00985

UNESCO, ICCROM, ICOMOS \& IUCN (2013) Managing Cultural World Heritage. Available at http://unesdoc.unesco.org/images/0022/002247/224787e.pdf

UNWTO (2001) Global Code of Ethics for Tourism. Available at http://cf.cdn.unwto.org/sites/all/files/docpdf/gcetbrochureglobalcodeen.pdf

UNWTO (2017) Second Global Report on Gastronomy Tourism. Available at http://cf.cdn.unwto.org/sites/all/files/pdf/gastronomy report web.pdf

University of Kansas (2016) Section 14. Strengths, Weaknesses, Opportunities and Threats. Community Tool Box. Available at: http://ctb.ku.edu/en/table-ofcontents/assessment/assessing-community-needs-and-resources/swotanalysis/main

Uy, A and Orillos, J (2015) Panaderia: Philippine Bread, Biscuit and Bakery Traditions. Mandaluyong City: Anvil Publishing Inc. Google Scholar search 
Visser, M (1991) The Rituals of Dinner: the origins, evolution, eccentricities and meaning of table manners. London: Grove Widenfeld. Google Scholar search

Westering, J (1999) Heritage and Gastronomy: the pursuit of the "new tourist". International Journal on Heritage Studies 5(2):75-81. Crossref

Zerrudo, E (2008) Pamanaraan: Writings on Philippine Cultural Heritage Management. UST Publishing House: Manila. Google Scholar search 